\title{
Effects of feeding brown midrib corn silage with a high dietary concentration of alfalfa hay on lactational performance of Holstein dairy cows for the first 180 days of lactation ${ }^{1}$
}

\author{
M. S. Holt, ${ }^{*}$ J.-S. Eun, ${ }^{2}$ C. R. Thacker, ${ }^{* 3}$ A. J. Young, ${ }^{*}$ X. Dai, $†$ and K. E. Nestor Jr.‡ \\ *Department of Animal, Dairy, and Veterinary Sciences, and \\ †Utah Agricultural Experiment Station, Utah State University, Logan 84322 \\ $\ddagger$ Mycogen Seeds, Indianapolis, IN 46268
}

\begin{abstract}
This experiment was conducted to test a hypothesis that lactating dairy cows fed $35 \%$ brown midrib (BMR) corn silage and $25 \%$ alfalfa hay (dry matter (DM) basis) would consume more DM around peak lactation compared with those fed conventional corn silage (CS), resulting in longer peak milk production. Twentyeight multiparous Holstein cows were used starting at the onset of lactation through $180 \mathrm{~d}$ in milk (DIM). Treatments were formulated to maintain a forage-toconcentrate ratio of 60:40, differing only in the CS hybrids used. Two dietary treatments were assessed in a completely randomized design: total mixed ration based on conventional CS (CCS) and total mixed ration based on BMR silage. Through peak lactation (1-60 DIM), DM intake was not different between dietary treatments, whereas DM intake post-peak lactation (61-180 DIM) tended to increase by feeding the BMR diet compared with the CCS diet (25.8 vs. $24.7 \mathrm{~kg} / \mathrm{d}$ ). Cows fed the BMR diet tended to lose less body weight through peak lactation compared with those fed the CCS diet $(-0.22$ vs. $-0.52 \mathrm{~kg} / \mathrm{d})$. Although milk yield was not different between dietary treatments through peak lactation, milk yield post-peak lactation increased by feeding the BMR diet compared with the CCS diet (41.0 vs. $38.8 \mathrm{~kg} / \mathrm{d}$ ). Yield of $3.5 \%$ fat-corrected milk was similar between dietary treatments throughout the experiment $(41.4 \mathrm{~kg} / \mathrm{d}$, on average), but milk fat concentration decreased by feeding the BMR diet compared with the CCS diet post-peak lactation (3.47 vs. $3.80 \%)$. Overall milk protein concentration was similar between dietary treatments throughout the experiment $(2.96 \%$, on average), whereas milk protein yield tended
\end{abstract}

Received June 20, 2012.

Accepted October 13, 2012.

${ }^{1}$ Approved as Journal Paper Number 8436 of the Utah Agricultural Experiment Station, Utah State University, Logan.

${ }^{2}$ Corresponding author: jseun@usu.edu

${ }^{3}$ Present address: School of Veterinary Medicine, Utah State University, Logan 84322. to be higher for the BMR diet post-peak lactation compared with the CCS diet (1.19 vs.1.13 kg/d). Feeding BMR silage with a high dietary concentration of alfalfa hay maintained more body weight, but did not affect milk production through peak lactation; however, cows fed the BMR diet post-peak lactation consumed more feed and maintained longer peak milk yield, leading to greater overall milk production and milk protein yield. Key words: brown midrib corn silage, alfalfa hay, stage of lactation, feed intake

\section{INTRODUCTION}

Observations by producers and dairy nutritionists indicate that over the past decade, dairy producers have increased their use of corn silage (CS) as a forage source in dairy rations. This has been influenced by the high price of feed, especially corn grain, and the high energy content of CS. Feeding forage levels at 55 to $60 \%$ of dietary DM is becoming more common, but lack of energy from concentrates and distention from rumen fill may limit DMI and reduce performance of high-producing dairy cows. Intake of DM is critical for dairy cows to achieve high milk production. Therefore, great emphasis has been placed on dietary factors affecting DMI of lactating dairy cows. Physical fill can be the most dominant mechanism limiting DMI for highyielding cows around peak lactation (Allen, 2000), but it may contribute less in early lactation (Ingvartsen and Andersen, 2000). During the transition period, control of feed intake is likely dominated by hepatic oxidation of NEFA (Allen et al., 2009). At freshening, DMI does not meet the energy requirements for maintenance and production of high-producing cows. This results in a negative energy balance accompanied by an increase in the incidence of various metabolic disorders and a reduction in reproductive performance (van Knegsel et al., 2005). Thus, minimizing negative energy balance and maximizing energy intake are among the most critical management aspects associated with feeding dairy cows in early lactation. Finding an optimal bal- 
ance between physically effective fiber and readily fermentable carbohydrates is difficult but crucial not only for maintaining proper ruminal metabolism (Zebeli et al., 2006; Plaizier et al., 2008), but also for maintaining a stable metabolic health status while enhancing productivity (Ametaj et al., 2010; Zebeli et al., 2011).

Peak milk yield can be maximized by feeding diets with low rumen-fill capacity that are typically highly fermentable. The rumen-filling effect of diets is influenced most by concentration, digestibility, and fragility of forage NDF (Allen and Bradford, 2011). Feeding forages with enhanced digestibility of NDF has been reported to improve DMI and milk yield (Oba and Allen, 1999). Corn silage with the brown midrib mutation has been well documented to have higher fiber degradability and will likely increase DMI and milk yield compared with cows fed conventional corn silage (CCS; Eastridge, 1999; Gencoglu et al., 2008). Several (Ebling and Kung, 2004; Gehman et al., 2008; Castro et al., 2010), but not all experiments (Taylor and Allen, 2005c; Weiss and Wyatt, 2006; Kung et al., 2008) feeding brown midrib (BMR) silage, have reported improved lactational performance of dairy cows. Inconsistent effects of BMR silage have been caused by various factors, including cows differing in the physiological state and duration of experiment (Taylor and Allen, 2005a; Castro et al., 2010). Therefore, understanding physiological changes occurring through lactation and the control of feed intake are critical to diet formulation for BMR silage-based diets.

We hypothesized that feeding $35 \%$ BMR silage in a $60 \%$ forage diet (DM basis) would result in increased DMI of lactating dairy cows around peak lactation compared with feeding CCS, causing longer peak milk production. The objective of this study was to evaluate the long-term effects of feeding BMR silage with good-quality alfalfa hay (AH) on DMI, productivity, and $\mathrm{BW}$ of high-producing dairy cows from the onset of lactation through 180 DIM.

\section{MATERIALS AND METHODS}

The dairy cows used in this study were cared for according to the Live Animal Use in Research Guidelines of the Institutional Animal Care and Use Committee at Utah State University, Logan. The study was conducted at the Caine Dairy Research Center (Wellsville, UT), Utah State University from February 9, 2011, to October 17, 2011.

\section{Cows and Experimental Diets}

Twenty-eight multiparous Holstein cows were used starting at the onset of lactation through 180 DIM. Two dietary treatments were tested in a completely randomized design. Cows were assigned to 1 of 2 dietary treatments $(n=14)$ based on previous milk yield and parity. Treatments were based on CCS (62.2\% 30-h NDF degradability) or BMR silage (71.4\% 30-h NDF degradability) with good-quality $\mathrm{AH}(20.6 \% \mathrm{CP}$ and $39.9 \% \mathrm{NDF}$ ) as the forage sources (Table 1). Treatments were formulated to maintain a forage-to-concentrate ratio of 60:40, differing only in the CS hybrids used. Treatments were TMR based on CCS and TMR based on BMR silage (Table 2). The diets were typical of high-producing dairy cows in the Intermountain West (i.e., Utah, Idaho, Wyoming, Montana, and parts of Arizona and Nevada) with $42 \%$ of the forage coming from good-quality AH. Rations were formulated based on NRC (2001) recommendations to provide sufficient $\mathrm{NE}_{\mathrm{L}}, \mathrm{MP}$, vitamins, and minerals to produce $40 \mathrm{~kg}$ of milk/d with $3.5 \%$ fat and $3.0 \%$ true protein, with the inclusion of Rumensin (Elanco Animal Health, Greenfield, IN).

Two CS hybrids, brown midrib corn hybrid (Mycogen F2F569; Mycogen Seeds, Indianapolis, IN) and conventional corn hybrid (DeKalb DKC61-72; Monsanto Co., St. Louis, MO) were planted during spring 2010 at the Utah State University South Farm (Wellsville).

Table 1. Chemical composition (means \pm SD) of forages $(n=8)$

\begin{tabular}{|c|c|c|c|}
\hline \multirow[b]{2}{*}{ Item } & \multicolumn{3}{|c|}{ Forage $^{1}$} \\
\hline & CCS & BMR & Alfalfa hay \\
\hline $\mathrm{DM}, \%$ & $29.2 \pm 2.20$ & $30.6 \pm 2.90$ & $90.7 \pm 1.60$ \\
\hline $\mathrm{OM}, \%$ of $\mathrm{DM}$ & $94.6 \pm 0.43$ & $93.4 \pm 0.46$ & $89.2 \pm 1.11$ \\
\hline $\mathrm{CP}, \%$ of DM & $8.62 \pm 0.25$ & $8.78 \pm 0.31$ & $20.6 \pm 0.35$ \\
\hline $\mathrm{NDF}, \%$ of DM & $46.4 \pm 2.12$ & $50.7 \pm 2.74$ & $39.9 \pm 4.34$ \\
\hline IVNDFD, ${ }^{2} \%$ & $62.2 \pm 2.96$ & $71.4 \pm 1.59$ & $\mathrm{ND}^{3}$ \\
\hline $\mathrm{ADF}, \%$ of $\mathrm{DM}$ & $24.9 \pm 1.60$ & $27.7 \pm 2.27$ & $29.4 \pm 3.50$ \\
\hline Starch, $\%$ of DM & $22.6 \pm 0.41$ & $21.7 \pm 0.37$ & ND \\
\hline
\end{tabular}


Table 2. Ingredients and chemical composition (means \pm SD) of the experimental diets fed to lactating cows $(\mathrm{n}=8)$

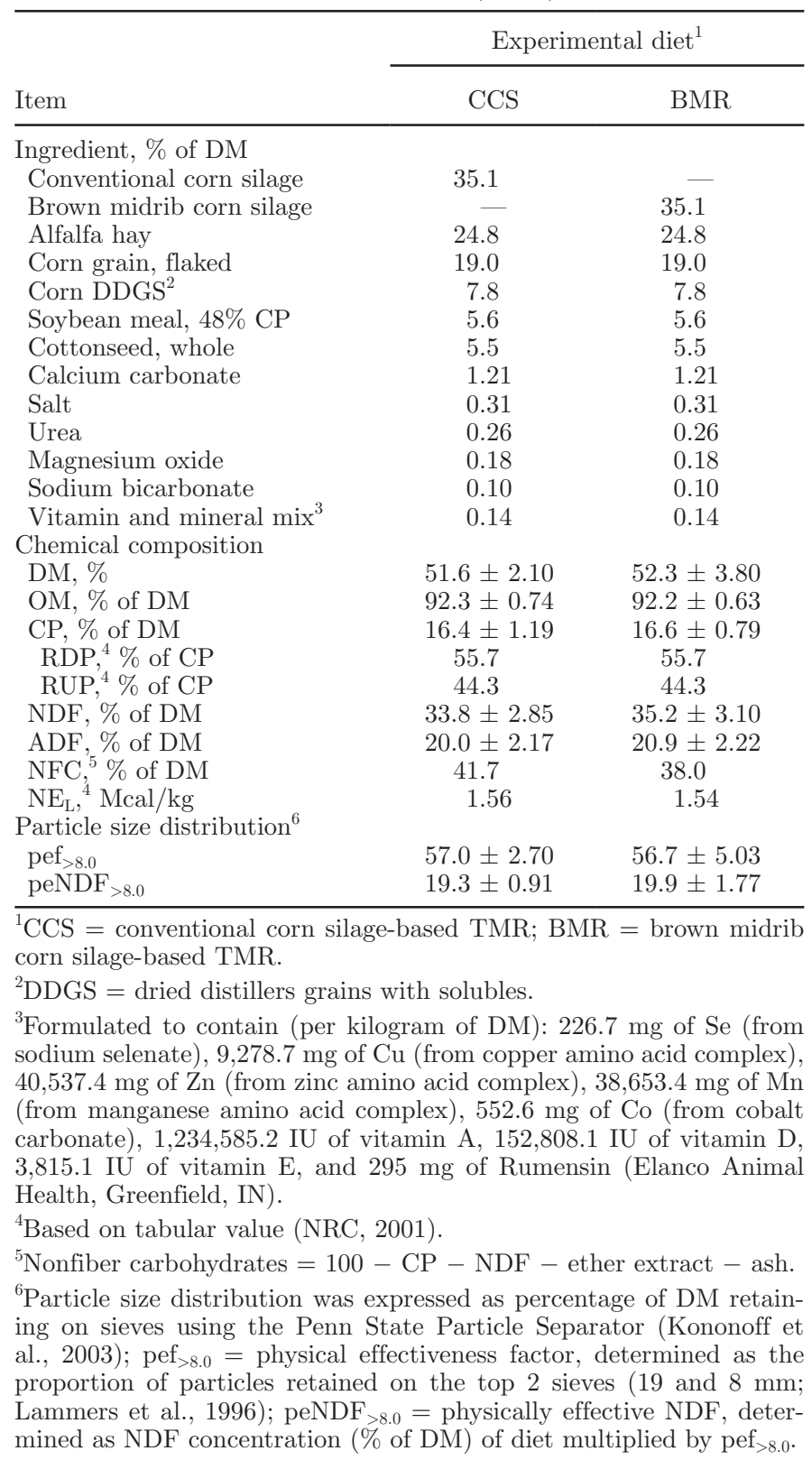

Corn silages were harvested at approximately 30\% whole plant DM using a New Holland FP230 pull-type harvester equipped with a mechanical processor (New Holland Agriculture, New Holland, PA). The harvested corn crops were treated with silage inoculant (Silage PT; Nurturite LLC, Twin Falls, ID) at a rate of 112 $\mathrm{g} / \mathrm{t}$ of fresh forage to enhance Lactobacillus fermentation and were ensiled separately in bag silos $(\mathrm{Ag} / \mathrm{Bag}$ International Ltd., Warrenton, OR).

Cows were housed in individual tiestalls fitted with rubber mattresses, bedded with straw, with free access to water. Cows were fed a TMR for ad libitum intake at $110 \%$ of the expected daily intake. All cows were individually fed twice daily at 0830 and $1500 \mathrm{~h}$ with approximately 70 and $30 \%$ of total daily feed allocation at each feeding, respectively. Feed offered and refused was recorded daily to determine DMI.

Cows were milked twice daily at 0400 and $1600 \mathrm{~h}$. Milk production was recorded daily throughout the experiment. Cows were turned outside to a dry lot for exercise for at least $1 \mathrm{~h}$ daily in the morning after being milked. Milk was sampled twice per month during the a.m. and p.m. milkings for 2 d. Milk samples were preserved with Broad Spectrum Microtabs II (D \& F Control Systems Inc., San Ramon, CA), and were stored at $4^{\circ} \mathrm{C}$. Individual milk samples were analyzed for fat, true protein, lactose, and MUN concentrations by the Rocky Mountain DHIA Laboratory (Logan, UT) with mid-infrared wave-bands (2 to $15 \mu \mathrm{m}$ ) procedures using an infrared instrument (Bentley 2000; Bentley Instruments Inc., Chaska, MN) calibrated weekly using raw milk standards provided by Eastern Laboratory Services Ltd. (Fairlawn, OH). An enzymatic procedure was used to determine MUN concentration using a ChemSpec 150 instrument (Bentley Instruments Inc.). Milk composition was expressed on weighted milk yield of a.m. and p.m. samples. Milk fat and protein yields were calculated by multiplying milk yield from the respective day by fat and protein concentration of the milk on an individual cow. All cows were weighed at 1 , 30, 60, 90, 120, 150, and 180 DIM.

\section{Feed Sampling and Analysis}

Corn silage and $\mathrm{AH}$ were sampled weekly to determine DM concentration. Diets were adjusted weekly to account for changes in DM concentration. Samples of each CS, AH, and TMR were taken each Monday and frozen immediately. In addition, orts for each treatment diet were sampled each Tuesday and frozen immediately. Frozen samples were thawed and composited by their sample type every month. Composited samples were dried at $60^{\circ} \mathrm{C}$ for $48 \mathrm{~h}$, ground to pass a $1-\mathrm{mm}$ screen (standard model 4; Arthur H. Thomas Co., Swedesboro, NJ), and stored for subsequent analyses.

Samples of TMR were collected every Monday for particle size analysis using the Penn State Particle Separator as described by Kononoff et al. (2003) equipped with 3 sieves $(19,8$, and $1.18 \mathrm{~mm}$ ) and a pan. The physical effectiveness factor (pef) for CS was calculated as the sum of the proportion of DM retained on 2 sieves (19 and $8 \mathrm{~mm}$; pef $_{>8.0}$; Lammers et al., 1996). The physically effective NDF (peNDF) content of the CS was calculated by multiplying NDF concentration of the feed (DM basis) by pef $>8.0\left(\mathbf{p e N D F}_{>8.0}\right)$. 
Analytical DM and OM concentration of samples was determined by oven drying at $105^{\circ} \mathrm{C}$ overnight and by ashing at $550^{\circ} \mathrm{C}$, respectively, whereas $\mathrm{N}$ concentration was determined using an elemental analyzer (LECO TruSpec N; Leco Corp., St. Joseph, MI; AOAC International, 2000). The NDF and ADF concentrations were sequentially determined using an $\mathrm{ANKOM}^{200 / 220}$ fiber analyzer (Ankom Technology Corp., Macedon, NY) according to the methodology supplied by the company, which is based on the methods described by Van Soest et al. (1991). Sodium sulfite and pretreatment with heat-stable amylase (Type XI-A from Bacillus subtilis; Sigma-Aldrich Corp., St. Louis, MO) was used in the procedure for NDF content determination.

\section{Analysis of Ruminal Fluid}

Ruminal fluid samples were obtained using a Geishauser probe $4 \mathrm{~h}$ after the morning feeding at 30, 60, 90, and 120 DIM. The fluid was collected with a solid, tube-like probe with rows of small holes on the end (Geishauser, 1993). The first $100 \mathrm{~mL}$ of ruminal fluid was discharged to avoid contamination from saliva, and then $10 \mathrm{~mL}$ was collected for analysis. The $\mathrm{pH}$ of the ruminal fluid was measured within $5 \mathrm{~min}$ of collecting the samples using a portable $\mathrm{pH}$ meter (Oakton pH 6; Oakton Instruments, Vernon Hills, IL). Five milliliters of the ruminal fluid was mixed with 1 $\mathrm{mL}$ of $1 \%$ sulfuric acid and stored frozen $\left(-40^{\circ} \mathrm{C}\right)$ for $\mathrm{NH}_{3}-\mathrm{N}$ analysis. Concentration of $\mathrm{NH}_{3}-\mathrm{N}$ in the ruminal contents was determined as described by Rhine et al. (1998), using a plate reader (MRX ${ }^{\mathrm{e}}$; Dynex Technologies Inc., Chantilly, VA). Another $5 \mathrm{~mL}$ of the ruminal fluid was collected and mixed with $1 \mathrm{~mL}$ of $25 \%$ metaphosphoric acid, and then stored at $-40^{\circ} \mathrm{C}$ for VFA content determination. Ruminal VFA were separated and quantified using a GLC (model 6890 series II; Hewlett-Packard Co., Avondale, PA) with a capillary column $(30 \mathrm{~m} \times 0.32-\mathrm{mm}$ i.d., $1-\mu \mathrm{m}$ phase thickness, Zebron ZB-FAAP; Phenomenex Inc., Torrance, CA) and flame-ionization detection. The oven temperature was held at $170^{\circ} \mathrm{C}$ for $4 \mathrm{~min}$, increased to $185^{\circ} \mathrm{C}$ at a rate of $5^{\circ} \mathrm{C} / \mathrm{min}$, then increased by $3^{\circ} \mathrm{C} / \mathrm{min}$ to $220^{\circ} \mathrm{C}$, and held at this temperature for $1 \mathrm{~min}$. The injector and the detector temperatures were 225 and $250^{\circ} \mathrm{C}$, respectively, and the carrier gas was helium (Eun and Beauchemin, 2007).

\section{Statistical Analyses}

All data were analyzed to characterize cows at 2 stages of lactation: through peak lactation (1-60 DIM) and post-peak lactation (61-180 DIM). This approach was based on the fact that mechanisms regulating voluntary feed intake, mobilization of body fat stores, and milk production differ by stage of lactation (Allen et al., 2009; Allen and Bradford, 2011). Data were analyzed using the PROC GLIMMIX SAS (SAS Institute, 2011) using a model that included type of CS as fixed effect, and cow as a random effect. Covariance structure first-order autoregressive 1 was used for the repeated measures by day, as it resulted in the lowest values for the Akaike information criteria and Schwartz Bayesian criterion. In addition, data for DMI, milk yield, and BW change were averaged at 30-d intervals and analyzed using the same model described above to present overall patterns of the measurements in Figures 1, 2, and 3, respectively. Data for ruminal fermentation parameters ( $\mathrm{pH}, \mathrm{VFA}$, and $\mathrm{NH}_{3}-\mathrm{N}$ ) were similarly analyzed; however, due to the lack of differences in the measurements throughout experiment, overall means were compared between treatments. Least squares means are reported throughout. Treatment effects were declared significant at $P<0.05$, and differences were considered to indicate a trend toward significance at $P<0.10$.

\section{RESULTS AND DISCUSSION}

\section{Characteristics of CS and Diets}

Chemical compositions of the forages fed during the experiment are outlined in Table 1. Mean concentrations of DM and CP were similar between the CCS and the BMR silage. On average, concentrations of NDF and ADF were slightly higher for the BMR silage than the CCS. This could have been due to the growing

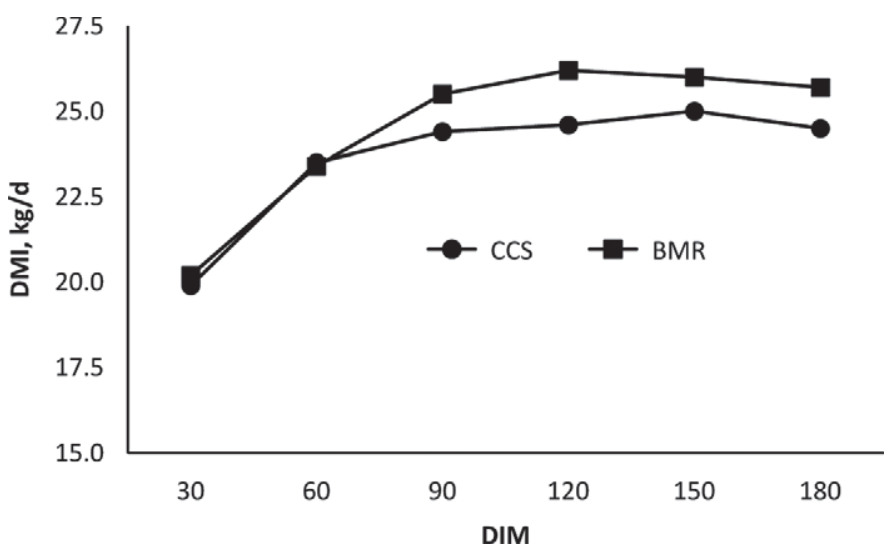

Figure 1. Effects of feeding corn silage-based diets on DMI averaged at 30-d intervals for Holstein dairy cows from the onset of lactation through 180 DIM. Dietary treatments were conventional corn silage-based TMR (CCS) and brown midrib corn silage-based TMR (BMR). Each point represents the mean of 14 cows. Over the entire 180-d experiment, LSM for DMI was 23.7 and $24.5 \mathrm{~kg} / \mathrm{d}$ for the CCS and the BMR silage, respectively, whereas effect of dietary treatments was $P=0.06$, with SEM $=0.28$. 


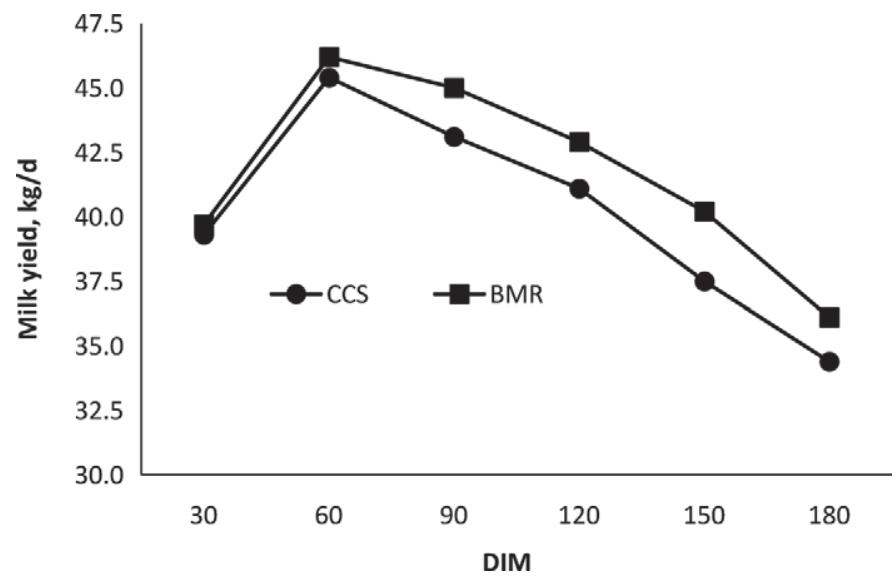

Figure 2. Effects of feeding corn silage-based diets on milk yield averaged at 30-d intervals for Holstein dairy cows from the onset of lactation through 180 DIM. Dietary treatments were conventional corn silage-based TMR (CCS) and brown midrib corn silage-based TMR (BMR). Each point represents the mean of 14 cows. Over the entire 180-d experiment, LSM for milk yield was 40.0 and $41.7 \mathrm{~kg} / \mathrm{d}$ for the CCS and the BMR silage, respectively, whereas effect of dietary treatments was $P<0.01$, with $\mathrm{SEM}=0.42$.

season being shorter and colder than normal, forcing silage to be harvested at less than optimal maturity, limiting grain fill, and causing a higher concentration of NDF. In vitro NDF degradability measured after $30 \mathrm{~h}$ of incubation was 9.2 percentage units higher for the BMR silage compared with the CCS. Dado and Allen (1995) speculated that a faster disappearance of NDF from the rumen because of increased rate of NDF digestion may reduce distention from gut fill over time and allow greater voluntary feed intake. Increased NDF degradability also increases the energy density of diets and stimulates microbial N production (Oba and Allen, 2000b). Jung et al. (2004) reported that a 1 percentage unit increase in in vitro NDF degradability of CS resulted in a $0.12 \mathrm{~kg} / \mathrm{d}$ increase in DMI and a $0.14 \mathrm{~kg} / \mathrm{d}$ increase in $3.5 \% \mathrm{FCM}$ yield for diets containing greater than $40 \%$ CS (DM basis). Thus, the increase in NDF degradation in BMR silage observed in our study has the potential to substantially improve the productivity of dairy cows fed diets containing BMR silage.

Ingredients and chemical composition of experimental diets are listed in Table 2. Although differences existed in NDF concentration between CS hybrids causing the diets to be slightly higher in NDF for the BMR diet (35.2 and $33.8 \%$ for the BMR diet and the CCS diet, respectively), diets contained similar $\mathrm{CP}$ and $\mathrm{NE}_{\mathrm{L}}(16.5 \%$ and $1.55 \mathrm{Mcal} / \mathrm{kg}$, on average, respectively). Physically effective factor and peNDF $>8.0$ were also similar between treatments (56.9 and $19.6 \%$, on average, respectively). The formation, maintenance, and consistency of the rumen mat strongly depend on dietary peNDF (Zebeli et al., 2012). However, feeding diets with an excess of peNDF $_{>8.0}$ was shown to decrease feed intake and feed efficiency (Yang and Beauchemin, 2007; Zebeli et al., 2008). Zebeli et al. (2012) report that $\operatorname{peNDF}_{>8.0}$ is a good predictor of physical fill in the reticulorumen and recommend feeding diets with a peNDF $>8.0$ of 16.4 to $20.6 \%$ to improve rumination and ruminal $\mathrm{pH}$ without limiting DMI of lactating dairy cattle. Treatments from our experiment were within this range.

\section{Intake, Milk Production, and BW}

Productive performance is reported in Tables 3 and 4 for the results through peak lactation and post-peak lactation, respectively. Intake of DM through peak lactation was not different between dietary treatments. However, DMI post-peak lactation tended to increase by feeding the BMR diet compared with the CCS diet (25.8 vs. $24.7 \mathrm{~kg} / \mathrm{d} ; P=0.07$ ). This suggests that ruminal distention from gut fill was not a limiting factor during the first several weeks of lactation. This can be explained with the hepatic oxidation theory proposed by Allen et al. (2009) who stated that DMI in the first few weeks of lactation is controlled primarily by oxidation of fuels in the liver that sends satiety signals to the brain. As cows move out of a negative energy balance several weeks after parturition, DMI starts to increase, whereas lipolysis and plasma NEFA concentration decrease, creating less NEFA available for oxidation in the liver, and then feed intake control by hepatic oxidation diminishes (Allen et al., 2009). Therefore, around

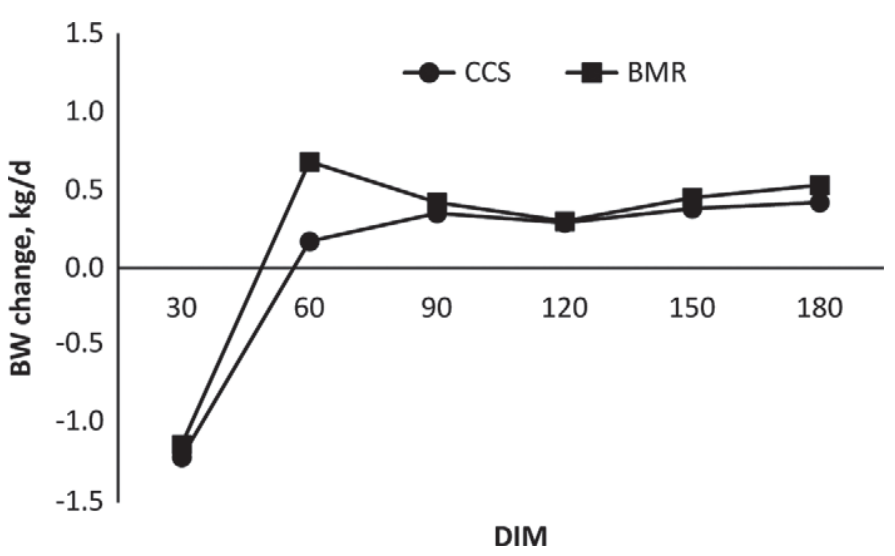

Figure 3. Effects of feeding corn silage-based diets on BW change averaged at 30-d intervals for Holstein dairy cows from the onset of lactation through 180 DIM. Dietary treatments were conventional corn silage-based TMR (CCS) and brown midrib corn silage-based TMR (BMR). Each point represents the mean of 14 cows. Over the entire 180-d experiment, LSM for BW change was 0.07 and $0.19 \mathrm{~kg} / \mathrm{d}$ for the CCS and the BMR silage, respectively, whereas effect of dietary treatments was $P=0.24$, with $\mathrm{SEM}=0.072$. 
Table 3. Productive performance of Holstein dairy cows fed corn silage-based diets through peak lactation $(1-60$ DIM)

\begin{tabular}{|c|c|c|c|c|}
\hline \multirow[b]{2}{*}{ Item } & \multicolumn{2}{|c|}{$\operatorname{Diet}^{1}$} & \multirow[b]{2}{*}{ SEM } & \multirow[b]{2}{*}{$P$-value } \\
\hline & CCS & BMR & & \\
\hline DMI, $\mathrm{kg} / \mathrm{d}$ & 21.7 & 21.7 & 0.34 & 0.94 \\
\hline DMI, $\%$ of BW & 3.23 & 3.36 & 0.110 & 0.41 \\
\hline Milk yield, kg/d & 42.3 & 43.1 & 0.68 & 0.49 \\
\hline $3.5 \%$ FCM yield, $\mathrm{kg} / \mathrm{d}$ & 45.6 & 45.0 & 1.72 & 0.80 \\
\hline \multicolumn{5}{|l|}{ Milk component } \\
\hline Fat, $\%$ & 3.97 & 3.70 & 0.124 & 0.13 \\
\hline Protein, \% & 2.91 & 2.94 & 0.051 & 0.76 \\
\hline Lactose, \% & 4.85 & 4.85 & 0.033 & 0.87 \\
\hline MUN, mg/100 mL & 12.7 & 13.1 & 0.28 & 0.30 \\
\hline \multicolumn{5}{|c|}{ Milk component yield, $\mathrm{kg} / \mathrm{d}$} \\
\hline Fat & 1.68 & 1.61 & 0.078 & 0.58 \\
\hline Protein & 1.22 & 1.27 & 0.042 & 0.46 \\
\hline Lactose & 2.06 & 2.10 & 0.055 & 0.56 \\
\hline $3.5 \%$ FCM yield/DMI & 2.14 & 2.10 & 0.074 & 0.69 \\
\hline Mean BW, kg & 709 & 689 & 17.0 & 0.40 \\
\hline BW change, $\mathrm{kg} / \mathrm{d}$ & -0.52 & -0.19 & 0.127 & 0.09 \\
\hline
\end{tabular}

${ }^{1} \mathrm{CCS}=$ conventional corn silage-based TMR; BMR = brown midrib corn silage-based TMR.

peak lactation, ruminal distension from gut fill becomes the dominant mechanism to control intake (Allen et al., 2009), and feeding diets with increased NDF degradability such as BMR silage may allow for greater feed intake (Oba and Allen, 2000a). The BMR silage hybrid has been shown to increase intake in some (Ebling and Kung, 2004; Gehman et al., 2008; Castro et al., 2010), but not all (Taylor and Allen, 2005c; Weiss and Wyatt, 2006; Kung et al., 2008) studies conducted during midlactation. Kung et al. (2008) speculated that the lack of effect on intake with feeding BMR silage may be associated with relatively short experimental periods (mostly less than $4 \mathrm{wk}$ ), which may not have been suf- ficient to cause differences in intake to be expressed when cows are fed with BMR silage. Results of DMI from our experiment averaged at 30-d intervals from the onset of lactation through 180 DIM depicted in Figure 1 support the importance of investigating the intake pattern of dairy cows during relatively longer period. In our case, we observed that cows fed the BMR diet increased DMI post-peak lactation compared with those fed the CCS diet.

Milk yield was not different between dietary treatments through peak lactation, whereas milk yield postpeak lactation increased by feeding BMR diet compared with the CCS diet (41.0 vs. $38.8 \mathrm{~kg} / \mathrm{d})$. The increases in

Table 4. Productive performance of Holstein dairy cows fed corn silage-based diets post-peak lactation (6-180 DIM)

\begin{tabular}{|c|c|c|c|c|}
\hline \multirow[b]{2}{*}{ Item } & \multicolumn{2}{|c|}{$\operatorname{Diet}^{1}$} & \multirow[b]{2}{*}{ SEM } & \multirow[b]{2}{*}{$P$-value } \\
\hline & CCS & BMR & & \\
\hline DMI, $\mathrm{kg} / \mathrm{d}$ & 24.7 & 25.8 & 0.41 & 0.07 \\
\hline DMI, $\%$ of BW & 3.48 & 3.67 & 0.112 & 0.27 \\
\hline Milk yield, $\mathrm{kg} / \mathrm{d}$ & 38.8 & 41.0 & 0.51 & $<0.01$ \\
\hline $3.5 \%$ FCM yield, $\mathrm{kg} / \mathrm{d}$ & 39.0 & 40.0 & 0.98 & 0.46 \\
\hline \multicolumn{5}{|l|}{ Milk component } \\
\hline Fat, $\%$ & 3.80 & 3.47 & 0.085 & 0.01 \\
\hline Protein, \% & 2.97 & 2.98 & 0.042 & 0.86 \\
\hline Lactose, $\%$ & 4.93 & 4.93 & 0.029 & 0.27 \\
\hline MUN, mg/100 mL & 12.6 & 13.5 & 0.29 & 0.03 \\
\hline \multicolumn{5}{|c|}{ Milk component yield, $\mathrm{kg} / \mathrm{d}$} \\
\hline Fat & 1.40 & 1.40 & 0.045 & 0.93 \\
\hline Protein & 1.13 & 1.19 & 0.031 & 0.10 \\
\hline Lactose & 1.86 & 1.96 & 0.045 & 0.14 \\
\hline $3.5 \%$ FCM yield/DMI & 1.58 & 1.55 & 0.055 & 0.89 \\
\hline Mean BW, kg & 725 & 720 & 14.9 & 0.81 \\
\hline BW change, $\mathrm{kg} / \mathrm{d}$ & 0.35 & 0.42 & 0.063 & 0.56 \\
\hline
\end{tabular}

${ }^{1} \mathrm{CCS}=$ conventional corn silage-based TMR; BMR = brown midrib corn silage-based TMR. 
DMI of $1.1 \mathrm{~kg} / \mathrm{d}$ and milk yield of $2.2 \mathrm{~kg} / \mathrm{d}$ are similar to those from previous research conducted with BMR silage. In the literature, cows fed BMR silage have generally been more productive than those fed CCS. Gencoglu et al. (2008) reported in a contemporary review of published experiments $(\mathrm{n}=11)$ that cows fed BMR silage averaged $1.2 \mathrm{~kg} / \mathrm{d}$ higher DMI and $1.7 \mathrm{~kg} / \mathrm{d}$ more milk than those fed CCS. Tine et al. (2001) reported that BMR silage provided greater amounts of energy due to the increased fiber digestibility when fed to dry cows at maintenance, but the estimated differences in energy values of BMR silage were smaller when fed to lactating cows. Those authors suggested that increases in milk production observed when feeding BMR silage may have been primarily driven by increases in DMI related to greater in vitro NDF degradability (Tine et al., 2001). However, not all studies that reported an increase in DMI had an increase in milk yield; some (Frenchick et al., 1976; Block et al., 1981; Gehman et al., 2008) fed a dietary protein concentration less than that recommended by NRC (2001), which may have limited the use of the additional energy intake. Castro et al. (2010) fed a dietary CP averaging 18.8\% and observed higher feed intakes for cows fed BMR silage without a significant response in milk yield, but cows may have used the extra intake energy to replenish BW. Similar to the pattern for DMI, milk yield increased with the BMR diet compared with the CCS diet post-peak lactation (Figure 2).

Yield of 3.5\% FCM was similar between dietary treatments throughout the experiment $(41.4 \mathrm{~kg} / \mathrm{d}$, on average), but milk fat concentration decreased by feeding the BMR diet compared with the CCS diet post-peak lactation (3.47 vs. $3.80 \%$ ). The yield of $3.5 \%$ FCM was equal, because the yield of milk fat was not affected by CS treatments. This is consistent with previous studies where the yield of milk fat was not affected by CS hybrids, but milk fat concentration was reduced for cows fed BMR silage (Qiu et al., 2003; Taylor and Allen, 2005c; Weiss and Wyatt, 2006). Overall milk protein concentration was similar between dietary treatments throughout the experiment $(2.96 \%$, on average), whereas post-peak milk protein yield tended to be higher for the BMR diet than the CCS diet (1.19 vs. $1.13 \mathrm{~kg} / \mathrm{d}$; $P=0.10)$. Oba and Allen (1999) suggested that increased DMI and diet fermentability of BMR silage can enhance microbial protein yield and flow to the small intestine, hence supplying more MP to the cow. Some studies that observed an increase in DMI due to feeding BMR silage also reported an increase in milk protein yield (Oba and Allen, 1999; Qiu et al., 2003; Kung et al., 2008). However, not all reports observing increased DMI reported increased milk protein yield (Gehman et al., 2008; Castro et al., 2010). The concentration of MUN is used as an indicator of protein nutrition status and efficiency of $\mathrm{N}$ utilization for dairy cows. Although feeding the BMR diet significantly increased MUN concentration post-peak lactation compared with the CCS diet in the current study, its difference was relatively small $(0.8 \mathrm{mg} / 100 \mathrm{~mL})$. Feeding different CS hybrids did not affect feed efficiency expressed as $3.5 \%$ FCM yield per DMI.

Whereas BW change through peak lactation tended $(P=0.09)$ to be less for cows fed the BMR diet compared with those fed the CCS diet $(-0.22$ vs. -0.52 $\mathrm{kg} / \mathrm{d}$; Table 3), BW change post-peak lactation was not different between dietary treatments. Other studies have reported similar numeric increases $(0.2 \mathrm{~kg} / \mathrm{d}$, on average) in BW gain for cows fed BMR silage (Taylor and Allen, 2005c; Gehman et al., 2008; Castro et al., 2010). Sommerfeldt et al. (1979) observed increased BW gains $(0.1 \mathrm{~kg} / \mathrm{d})$ for cows fed BMR silage in early lactation (42 DIM, on average) with no advantage in DMI and milk yield compared with those fed a CCS diet, suggesting that the BMR diet had a slight advantage in energy that was partitioned toward body tissue during early lactation. In a study conducted to evaluate the energy balance of dairy cattle fed BMR silage, Tine et al. (2001) reported an increase in DMI of $2.4 \mathrm{~kg} / \mathrm{d}$ for cows post-peak lactation that resulted in an extra energy intake of $8.8 \mathrm{Mcal} / \mathrm{d}$. Most of the extra energy intake was partitioned toward body tissue at $45 \%$, with $36 \%$ lost as heat and $18 \%$ used for milk production. However, energy utilization is affected by several variables; Taylor and Allen (2005c) stated that the capacity of the mammary gland to use nutrients for milk is influenced by hormone secretion and clearance, insulin resistance of tissues, and nutrient demands of various tissues, which are all influenced by the stage of lactation and milk production. The pattern of BW change is shown in Figure 3, and cows fed the BMR diet resulted in the smallest loss of BW in the first 60 DIM compared with those fed the CCS diet.

\section{Ruminal Fermentation Profiles}

Ruminal $\mathrm{pH}$ measured at $4 \mathrm{~h}$ postfeeding was similar between treatments $(6.28$, on average, throughout the study; Table 5). Some studies reported a decrease in ruminal $\mathrm{pH}$ when BMR silage was fed (Oba and Allen, 2000a; Taylor and Allen, 2005b; Gehman et al., 2008). This may have been caused by the increased supply of fermentable substrate in the rumen due to enhanced NDF digestibility of BMR silage (Weiss and Wyatt, 2006). In our study, AH was fed at the expense of $\mathrm{CS}$, which would have increased ruminal $\mathrm{pH}$ for both treatments due to the higher buffering capacity of $\mathrm{AH}$ compared with CS (Erdman et al., 2011). In our pre- 
Table 5. Ruminal fermentation characteristics of Holstein dairy cows fed corn silage-based diets from the onset of lactation through 180 DIM

\begin{tabular}{|c|c|c|c|c|}
\hline \multirow[b]{2}{*}{ Item } & \multicolumn{2}{|c|}{ Diet $^{1}$} & \multirow[b]{2}{*}{ SEM } & \multirow[b]{2}{*}{$P$-value } \\
\hline & CCS & BMR & & \\
\hline Mean pH & 6.29 & 6.27 & 0.072 & 0.85 \\
\hline Total VFA, $\mathrm{m} M$ & 107.2 & 109.9 & 2.30 & 0.42 \\
\hline \multicolumn{5}{|c|}{ Individual VFA, mol/100 mL } \\
\hline Acetate $(\mathrm{A})$ & 61.2 & 60.9 & 0.59 & 0.75 \\
\hline Propionate $(\mathrm{P})$ & 25.2 & 23.3 & 1.13 & 0.27 \\
\hline Butyrate & 11.5 & 11.4 & 0.18 & 0.88 \\
\hline Valerate & 1.78 & 1.74 & 0.088 & 0.74 \\
\hline Isobutyrate & 0.84 & 0.75 & 0.044 & 0.18 \\
\hline Isovalerate & 1.34 & 1.32 & 0.065 & 0.81 \\
\hline $\mathrm{A}: \mathrm{P}$ & 2.64 & 2.63 & 0.098 & 0.92 \\
\hline $\mathrm{NH}_{3}-\mathrm{N}, \mathrm{mg} / 100 \mathrm{~mL}$ & 8.27 & 9.03 & 0.437 & 0.24 \\
\hline
\end{tabular}

${ }^{1} \mathrm{CCS}=$ conventional corn silage-based TMR; BMR = brown midrib corn silage-based TMR.

vious study, where high dietary concentrations of $\mathrm{AH}$ ( $25 \%$ of DM) were fed with BMR silage, we reported that mean ruminal $\mathrm{pH}(6.30$, on average) were similar between CCS-based diets and BMR silage-based diets, with episodes less than 5.8 rarely occurring (Holt et al., 2010). Other studies showed that replacing a portion of CS with alfalfa silage increased ruminal $\mathrm{pH}$ (Krause and Combs, 2003; Brito and Broderick, 2006). Despite the increase in DMI due to feeding the BMR diet postpeak lactation, dietary treatments did not influence total VFA concentration and their individual molar proportions and $\mathrm{NH}_{3}-\mathrm{N}$ concentration throughout the experiment. Although BMR silage had greater NDF degradability and increased DMI and milk production post-peak lactation, no effects on ruminal fermentation characteristics were observed throughout the experiment.

\section{CONCLUSIONS}

Feeding BMR silage in high-forage diets with a high concentration of good-quality AH maintained higher BW after parturition even though DMI was similar through peak lactation. Ruminal distention from gut fill did not appear to be a limiting factor for DMI during the early weeks of lactation. As cows moved into a positive energy balance, the mechanism limiting DMI appeared to change, because DMI and milk production increased for cows fed the BMR diet compared with those fed the CCS diet. Controlling mobilization of body fat stores during transition and maximizing peak milk production are critical to improve animal health and farm profitability. Overall results reported in the current study indicate that feeding BMR silage in high-forage diets can have beneficial effects to lessen body fat mobilization in fresh cows without limiting DMI around peak lactation, resulting in longer peak milk production. Further research is needed to examine effects of feeding BMR silage on energy partitioning in transition cows with analysis of NEFA and BHBA to determine physiological effects of BMR silage on body fat mobilization in early lactation and BW gain in later lactation.

\section{ACKNOWLEDGMENTS}

This study was supported by funds from Mycogen Seeds (Indianapolis, IN) and Utah State University Agricultural Experiment Station (Logan). The authors thank C. Dschaak, K. Neal, and W. Burningham at Utah State University (Logan) for technical assistance and the staff of the Caine Dairy Research Center (Wellsville, UT) for their conscientious care of the experimental cows.

\section{REFERENCES}

Allen, M. S. 2000. Effects of diet on short-term regulation of feed intake by lactating dairy cattle. J. Dairy Sci. 83:1598-1624.

Allen, M. S., and B. J. Bradford. 2011. Control of energy intake through lactation. Pages 169-179 in Proc. Western Dairy Management Conf., Reno, NV.

Allen, M. S., B. J. Bradford, and M. Oba. 2009. Board-Invited Review: The hepatic oxidation theory of the control of feed intake and its application to ruminants. J. Anim. Sci. 87:3317-3334.

Ametaj, B. N., Q. Zebeli, F. Saleem, N. Psychogios, M. J. Lewis, S. M. Dunn, J. Xia, and D. S. Wishart. 2010. Metabolomics reveals unhealthy alterations in rumen metabolism with increased proportion of cereal grain in the diet of dairy cows. Metabolomics 6:583-594.

AOAC International. 2000. Official Methods of Analysis. Vol. 1 and 2. 17th ed. AOAC Int., Gaithersburg, MD.

Block, E., L. D. Muller, L. C. Griel Jr., and D. L. Garwood. 1981. Brown midrib-3 corn silage and heat extruded soybeans for early lactating dairy cows. J. Dairy Sci. 64:1813-1825.

Brito, A. F., and G. A. Broderick. 2006. Effect of varying dietary ratios of alfalfa silage to corn silage on production and nitrogen utilization in lactating dairy cows. J. Dairy Sci. 89:3924-3938.

Castro, J. J., J. K. Bernard, N. A. Mullis, and R. B. Eggleston. 2010. Brown midrib corn silage and Tifton 85 bermudagrass in rations for early-lactation cows. J. Dairy Sci. 93:2143-2152. 
Dado, R. G., and M. S. Allen. 1995. Intake limitations, feeding behavior, and rumen function of cows challenged with rumen fill from dietary fiber or inert bulk. J. Dairy Sci. 78:118-133.

Eastridge, M. L. 1999. Brown midrib corn silage. Pages 179-190 in Proc. Tri-State Dairy Nutrition Conf., Fort Wayne, IN. The Ohio State University, Columbus.

Ebling, T. L., and L. Kung Jr. 2004. A comparison of processed conventional corn silage to unprocessed and processed brown midrib corn silage on intake, digestion, and milk production by dairy cows. J. Dairy Sci. 87:2519-2526.

Erdman, R. A., L. S. Piperova, and R. A. Kohn. 2011. Corn silage versus corn silage:alfalfa hay mixtures for dairy cows: Effects of dietary potassium, calcium, and cation-anion difference. J. Dairy Sci. 94:5105-5110.

Eun, J.-S., and K. A. Beauchemin. 2007. Enhancing in vitro degradation of alfalfa hay and corn silage using feed enzymes. J. Dairy Sci. 90:2839-2851.

Frenchick, G. E., D. G. Johnson, J. M. Murphy, and D. E. Otterby. 1976. Brown midrib corn silage in dairy cattle rations. J. Dairy Sci. 59:2126-2129.

Gehman, A. M., P. J. Kononoff, C. R. Mullins, and B. N. Janicek. 2008. Evaluation of nitrogen utilization and the effects of monensin in dairy cows fed brown midrib corn silage. J. Dairy Sci. 91:288-300.

Geishauser, T. 1993. An instrument for the collection and transfer of ruminal fluid and for the administration of water soluble drugs in adult cattle. Bovine Pract. 27:38-42.

Gencoglu, H., R. Shaver, and J. Lauer. 2008. Brown midrib corn silage for lactating dairy cows: A contemporary review. Accessed May 20, 2012. http://www.uwex.edu/ces/dairynutrition/documents/ BMRfeedingtrialreview2008web.pdf.

Holt, M. S., C. M. Williams, C. M. Dschaak, J.-S. Eun, and A. J. Young. 2010. Effects of corn silage hybrids and dietary nonforage fiber sources on feed intake, digestibility, ruminal fermentation, and productive performance of lactating Holstein dairy cows. J. Dairy Sci. 93:5397-5407.

Ingvartsen, K. L., and J. B. Andersen. 2000. Integration of metabolism and intake regulation: A review focusing on periparturient animals. J. Dairy Sci. 83:1573-1597.

Jung, H. G., M. Raeth-Knight, and J. G. Linn. 2004. Forage fiber digestibility: Measurement, variability, and impact. Pages 105-125 in Proc. 65th Minnesota Nutr. Conf., St. Paul, MN. Univ. Minnesota, Minneapolis.

Kononoff, P. J., A. J. Heinrichs, and D. A. Buckmaster. 2003. Modification of the Penn State forage and total mixed ration particle separator and the effects of moisture content on its measurements. J. Dairy Sci. 86:1858-1863.

Krause, K. M., and D. K. Combs. 2003. Effects of forage particle size, forage source, and grain fermentability on performance and ruminal pH in midlactation cows. J. Dairy Sci. 86:1382-1397.

Kung, L., Jr., B. M. Moulder, C. M. Mulrooney, R. S. Teller, and R. J. Schmidt. 2008. The effect of silage cutting height on the nutritive value of a normal corn silage hybrid compared with brown midrib corn silage fed to lactating cows. J. Dairy Sci. 91:1451-1457.

Lammers, B. P., D. R. Buckmaster, and A. J. Heinrichs. 1996. A simple method for the analysis of particle size of forage and total mixed rations. J. Dairy Sci. 79:922-928.

NRC. 2001. Nutrient Requirements of Dairy Cattle. 7th rev. ed. Natl. Acad. Sci., Washington, DC.

Oba, M., and M. S. Allen. 1999. Effects of brown midrib 3 mutation in corn silage on dry matter intake and productivity of high yielding dairy cows. J. Dairy Sci. 82:135-142.

Oba, M., and M. S. Allen. 2000a. Effects of brown midrib 3 mutation in corn silage on productivity of dairy cows fed two concentrations of dietary neutral detergent fiber: 1 . Feeding behavior and nutrient utilization. J. Dairy Sci. 83:1333-1341.

Oba, M., and M. S. Allen. 2000b. Effects of brown midrib 3 mutation in corn silage on productivity of dairy cows fed two concentrations of dietary neutral detergent fiber: 3. Digestibility and microbial efficiency. J. Dairy Sci. 83:1350-1358.

Plaizier, J. C., D. O. Krause, G. N. Gozho, and B. W. McBride. 2008. Subacute ruminal acidosis in dairy cows: The physiological causes, incidence and consequences. Vet. J. 176:21-31.

Qiu, X., M. L. Eastridge, and Z. Wang. 2003. Effects of corn silage hybrid and dietary concentration of forage NDF on digestibility and performance by dairy cows. J. Dairy Sci. 86:3667-3674.

Rhine, E. D., G. K. Sims, R. L. Mulvaney, and E. J. Pratt. 1998. Improving the Berthelot reaction for determining ammonium in soil extracts and water. Soil Sci. Soc. Am. J. 62:473-480.

SAS Institute. 2011. SAS/STAT User's Guide. Release 9.3. SAS Institute Inc., Cary, NC.

Sommerfeldt, J. L., D. J. Schingoethe, and L. D. Muller. 1979. Brownmidrib corn silage for lactating dairy cows. J. Dairy Sci. 62:16111618

Taylor, C. C., and M. S. Allen. 2005a. Corn grain endosperm type and brown midrib 3 corn silage: Site of digestion and ruminal digestion kinetics in lactating cows. J. Dairy Sci. 88:1413-1424.

Taylor, C. C., and M. S. Allen. 2005b. Corn grain endosperm type and brown midrib 3 corn silage: Ruminal fermentation and N partitioning in lactating cows. J. Dairy Sci. 88:1434-1442.

Taylor, C. C., and M. S. Allen. 2005c. Corn grain endosperm type and brown midrib 3 corn silage: Feeding behavior and milk yield of lactating cows. J. Dairy Sci. 88:1425-1433.

Tine, M. A., K. R. McLeod, R. A. Erdman, and R. L. Baldwin VI. 2001. Effects of brown midrib corn silage on the energy balance of dairy cattle. J. Dairy Sci. 84:885-895.

van Knegsel, A. T. M., H. van den Brand, J. Dijkstra, S. Tamminga, and B. Kemp. 2005. Effect of dietary energy source on energy balance, production, metabolic disorders and reproduction in lactating dairy cattle. Reprod. Nutr. Dev. 45:665-688.

Van Soest, P. J., J. B. Robertson, and B. A. Lewis. 1991. Methods of dietary fiber, neutral detergent fiber and nonstarch polysaccharides in relation to animal nutrition. J. Dairy Sci. 74:3583-3597.

Weiss, W. P., and D. J. Wyatt. 2006. Effect of corn silage hybrid and metabolizable protein supply on nitrogen metabolism of lactating dairy cows. J. Dairy Sci. 89:1644-1653.

Yang, W. Z., and K. A. Beauchemin. 2007. Altering physically effective fiber intake through forage proportion and particle length: Chewing and ruminal pH. J. Dairy Sci. 90:2826-2838.

Zebeli, Q., J. R. Aschenbach, M. Tafaj, J. Boguhn, B. N. Ametaj, and W. Drochner. 2012. Invited review: Role of physically effective fiber and estimation of dietary fiber adequacy in high-producing dairy cattle. J. Dairy Sci. 95:1041-1056.

Zebeli, Q., J. Dijkstra, M. Tafaj, H. Steingass, B. N. Ametaj, and W. Drochner. 2008. Modeling dietary fiber adequacy in dairy cows based on responses of ruminal $\mathrm{pH}$ and milk fat production to diet composition. J. Dairy Sci. 91:2046-2066.

Zebeli, Q.. S. M. Dunn, and B. N. Ametaj. 2011. Perturbations of plasma metabolites correlated with the rise of rumen endotoxin in dairy cows fed diets rich in easily degradable carbohydrates. J. Dairy Sci. 94:2374-2382.

Zebeli, Q., M. Tafaj, H. Steingass, B. Metzler, and W. Drochner. 2006. Effects of physically effective fiber on digestive processes and milk fat content in early lactating dairy cows fed total mixed rations. J. Dairy Sci. 89:651-668. 